\title{
Functional zoning of ecological tourism areas by degree of regulation of building and planning activities
}

\author{
Dmitry Astanin* \\ School of Engineering and Technology, Cherepovets State University, Cherepovets, \\ 162600, Russian Federation
}

\begin{abstract}
The article considers the problem of natural landscape conservation under exposure to recreation impacts and emphasizes the differences between international and Russian experiences in establishing functional zones of specially protected natural reserves. Zoning according to the Federal Law of the Russian Federation «On Specially Protected Natural Territories» and the «Seville Strategy for Biosphere Reserves» are indicated. Recommendations for functional zoning regulations depending on their degree of openness for tourism according to the Russian and international requirements are proposed.
\end{abstract}

\section{Introduction}

The use of nature for the purposes of mass recreation makes significant changes to the environment. The first principle of ecotourism is to minimize such impacts. The task of urban planning is to manage these processes at all the levels of design, contributing to the preservation of nature, the rational use of its resources and the creation of favorable conditions for tourism. Vladimirov V.V. emphasized that functional zoning of the territory is of particular importance in the complex of environmental measures. Kotlyarov Ye.A. who studied the recreational impact on the natural environment, wrote about the feasibility of identifying zones for various purposes in the territory of protected natural areas. He identified three main areas:

1. Especially valuable areas;

2. Zones of extensive recreational development;

3. Peripheral zones.

Thus, the planning measures that correspond to the first principle of ecotourism primarily include functional zoning of ecotourism territories, in which its individual plots are allocated for various uses in accordance with their natural features.

Planning organization of ecological tourism is based on the zonal type - each of the zones has its own system of planning elements. The basis of functional zoning is the landscape principle, where the zoning pattern is determined by the type of morphological structure of the landscape, and the zone mode determines the maximum allowable capacity

\footnotetext{
* Corresponding author: montenegro.astanin@mail.ru
} 
of landscapes. According to Strasdas and Ceballos-Lascurain, zones should be allocated in accordance with the natural and cultural values of the protected area, the recreational capacity of the plots and particularly vulnerable landscapes.

\section{Methodology}

\subsection{Functional zoning of biosphere reserves}

The basis of zoning ecotourism should be based on the ideology of biosphere territories, the concept of which was developed in 1974 by the working group of the Man and Biosphere program, and the main principles of which are formulated in the Seville Strategy of Biosphere Reserves. Since the main task of national parks is the preservation of natural landscapes, and for biosphere reserves the history of a positive relationship between man and nature is important, the development of environmental management methods adequate to local environmental conditions and cultural traditions. According to the Seville Strategy, the biosphere reserve should fulfill three functions:

1. Conservation - a contribution to the preservation of landscapes, ecosystems, species and genetic varieties;

2. Development - promoting economic, social, culturally and environmentally sustainable development;

3. Scientific and technical function - support for demonstration projects, environmental education and training in the field of the environment, research and monitoring related to local regional, national and global issues of environmental conservation and sustainable development.

Each biosphere reserve should include: one or more major areas (or cores) that enjoy longterm protection and allow for the preservation of biological diversity; a buffer zone located around the core and used for carrying out activities in the field of environmental education, leisure, ecotourism, etc ; Transition zone (cooperation zone) - a zone of regulated economic activity (agriculture, forest use). Settlements can be located here.

Core $(3-5 \%$ of the total area). The main goal is to preserve biodiversity. The size of this zone should enable the

ecosystem to function. Any capital construction is prohibited here.

The buffer zone $(20-10 \%$ of the total area) is a multifunctional area designed to integrate the social environment

into the natural environment. The goal is to reduce the human impact on the nucleus. The main function is to ensure the rational use of natural resources, perhaps the traditional use of natural resources. Long-term human settlement is unacceptable.

Transition zone $(50-75 \%$ of the total area). The goal is to ensure sustainable use of natural resources and socio-economic development of the region. The main function is the preservation of traditional cultural landscapes. It is possible to check.

According to UNESCO, where the threshold of ecological balance is exceeded, the goal is the restoration of nature.

In the 20th century, the model of division (segregation) of agricultural production and protected areas was widely used in environmental management, but the impossibility of large-scale land reservation for protected areas is becoming increasingly obvious. The development of the concept of biosphere reserves, where interaction with the local population in the zone of cooperation is an important part, is a step towards blurring the boundaries between protected areas and economic lands. At the beginning of the $21 \mathrm{st}$ century, the idea of mutual penetration was further developed within the concept of Ecoagriculture. Its essence is that the sustainable development of any landscape should be 
based on the unity of three components: effective agriculture, biodiversity and ecosystem services [13]. In 1990, the government of the GDR adopted the document "The program of organization of national parks, biosphere reserves and natural parks. As a result of the merger of the two environmental laws of Germany and the GDR in just one year was created 6 biosphere reserves, which later received the status of UNESCO.

There are 72 villages and three small towns in the reserve Schorfheide-Chorin. population is engaged in agriculture. There are 3 functional zones within the reserve:

1. Multicore protection zone $(1-2.8 \%$ of total land area) is entirely occupied by forests. Despite the fact that it should be used only for scientific purposes, hunting and fishing by extensive methods are allowed in some of its areas, since this has been a favorite hunting place for centuries and a complete ban will cause conflicts with the local population.

2.Protection zone 2 (buffer zone) - 19\% - walking on special trails is allowed here, it is possible to conduct agriculture with a ban on the use of chemical plant protection products. There are problems with tourist activities, as common cases of illegal residence in tents and swimming in prohibited areas.

3. Protection zone 3 (transition or cooperation zone) - $78.2 \%$. It has the status of a landscape reserve. At the same time, the status of the landscape reserve implies the protection, preservation and maintenance of landscapes of special value as recreation facilities.

During the construction of any objects on the territory of the reserve, regardless of the form of ownership of the land, the investor (tenant or owner) is obliged to apply to the territory of the reserve and obtain approval for the possibility and feasibility of their actions.

In the Schorfheide-Chorin Biosphere Reserve it is developed a four-level system of information and educational centers. Today agriculture on the territory of the SchorfheideChorin can serve as an example of sustainable nature management of the biosphere reserve. 48 enterprises, which occupy $25 \%$ of the agricultural land area, use environmentally sound farming methods. Many enterprises are engaged in active protection of landscapes. For example, the training sheepfold Friedrichsfeld grows 530 ewes. Along with the production of meat and wool, this company takes care of landscapes and biotopes outside its own production areas. Advertising activity provides a constant flow of tourists, and as a result increases the number of buyers of environmentally friendly products. There is established a demonstration site of ancient forms of environmental management In Blumberger Mühle , in Schorfheide a wild animal Park operates; and there is a garden of old varieties of cultivated plants in Greifenberg.

At the present stage in Russia there is no legislative base ensure the functioning of all three mandatory zones [39]. Most of the biosphere reserves in Russia [2], do not have legally approved buffer and transition zones, in which ecological tourism is primarily developed. In the absence of a transition zone, our biosphere reserves have not been able to create an optimal structure and manage it with the participation of the local population. Most of the biosphere reserves in Russia set the main task of monitoring the natural environment. The situation began to change when the status of biosphere reserves was first granted to national parks (Ugra, Vodlozersky,Smolensk lake district). In the existing legislation of Russia national parks correspond to the principles of activity of the biosphere reserve. In addition, two biosphere reserves have been created, where the reserves are only the core: the Nizhegorsk Zavolzhye (the Kerzhensky core reserve) and the Nerusso Desnyanskoye Polesie (the Bryansk forest core reserve). In our country, a protected area was created, originally designed as a biosphere - commander Islands [3]. 


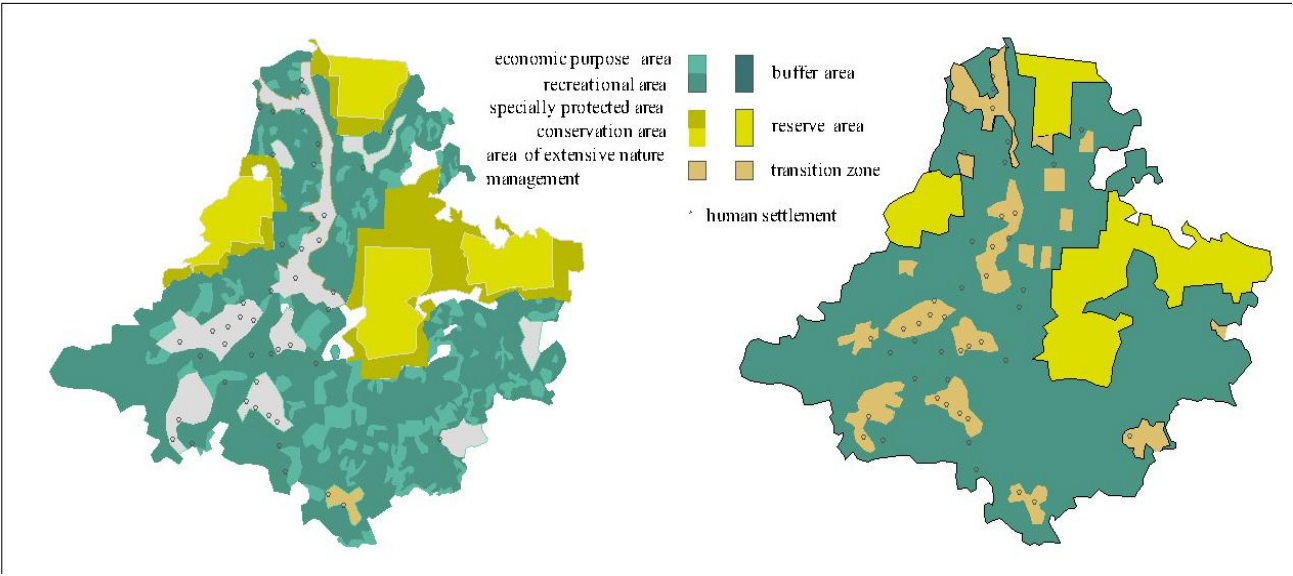

Fig. 1. Functional zoning of the Smolensk lake district National Park. Functional zoning of the Biosphere reserve Smolenskoye Poozerye.

During the organization of the Valdai biosphere reserve [4], nuclear and buffer zones were allocated on the valuable lands of the Park, and the zone of cooperation, including both the land of the Park and the land of other owners. At present, it is realized that for the territory in order to maintain biological diversity and recreational attractiveness, it is important to preserve traditional agriculture, possibly in several modified forms (rural tourism, shelters for fishermen). Within its boundaries 150 settlements, permanent residents of 36 thousand people. [5]. In the last decade, the flow of tourists has increased significantly in Valdai, there is an intensive development of residential land in the coastal areas of lakes, developing tourist infrastructure. Accordingly, the issues of management and monitoring of tourist and recreational activities, strengthening of environmental education, development of methods of control and restoration of recreational areas come to the fore before the biosphere reserve.

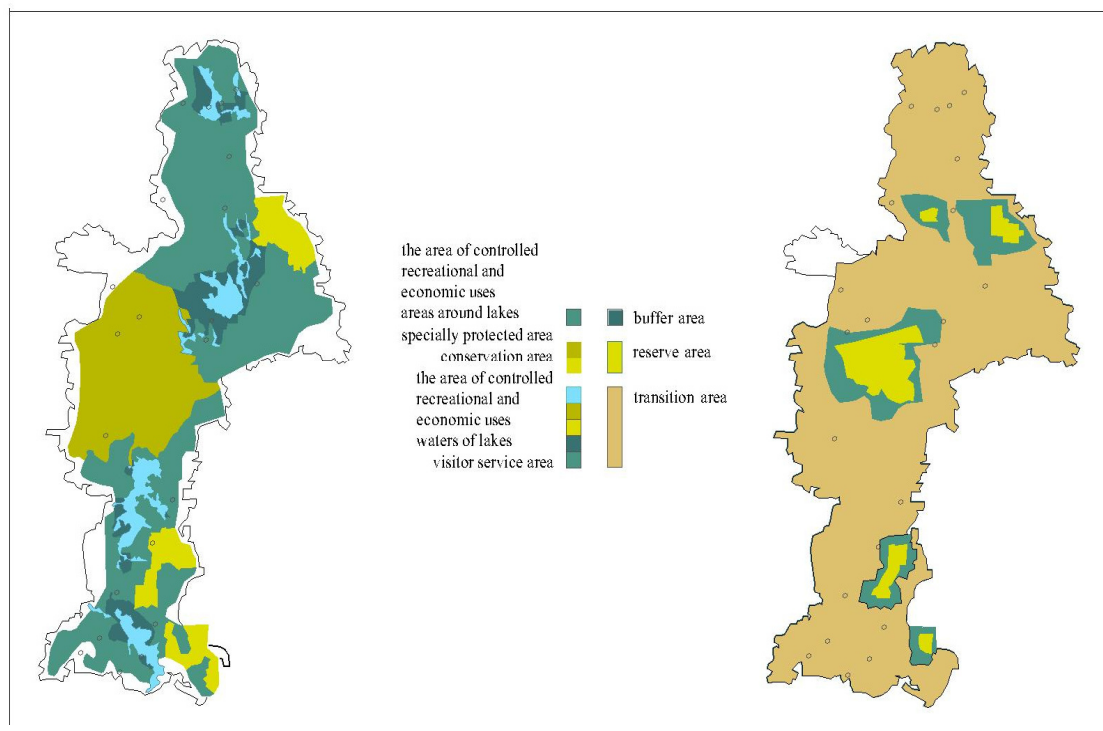

Fig. 2. Functional zoning of the Valdai national Park. Functional zoning of the Biosphere reserve of the Valdai. 
Biosphere reserve Vodlozersky - legally fixed area of strict protection of natural complexes, including the protected area of the national Park. It consists of three cores with valuable typical and unique natural complexes. Only short-term scientific research related to environmental monitoring is allowed here.

The buffer zone of the biosphere reserve includes specially protected, recreational and territory of traditional nature management. It includes the waters of the lake Vodlozero, islands and adjacent coastal areas, as well as most of the basin of the river Ileksa (Iloksa). On the territory of the buffer zone along with the protection function is carried out activities compatible with the tasks of conservation - research, tourism, recreation, traditional fishing, agriculture within the boundaries of historical lands.

The transitional zone includes a forest zone and 4500000 hectares of forest areas adjacent to the Park. There are 17 settlements, where more than 4,000 people live permanently. The main activity is forestry and forest industry. In the near future, in the transition zone of the reserve, it is planned to develop the largest in Russia Aganozero Deposit of chromium ores [7]. The zone has a developed infrastructure of forest roads. It is planned to conduct landscape and environmental planning of forestry and the introduction of technologies of gentle forest management. When developing a chrome ore Deposit, a wide range of measures for environmental protection and monitoring is planned. The vast area of the buffer zone and the transition zone, with a small population, create favorable conditions for improving the socio-economic conditions of the local population on the basis of the preservation and development of traditional environmentally safe forms of natural resources (fishing, agriculture, crafts), as well as services for tourists.

The national Park can fully implement the function of "conservation" as a biosphere reserve, as well as the function of "support for targeted research" within the boundaries of the nuclear and buffer zones, as well as the function of sustainable environmental management in the transition zone.

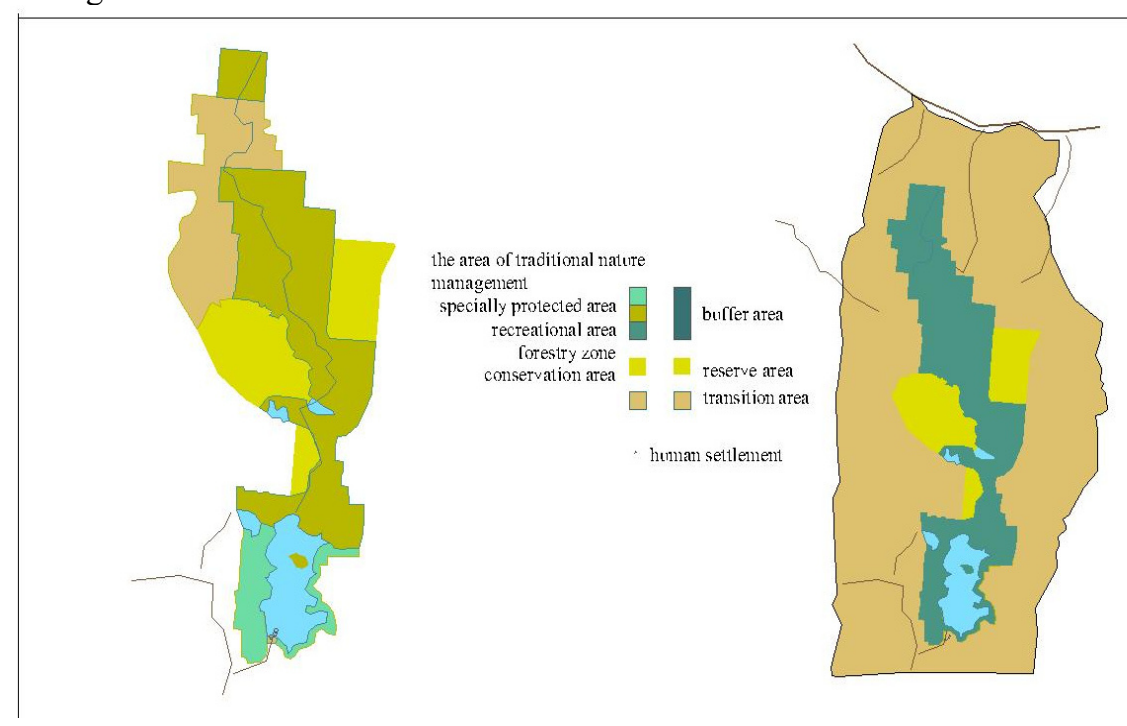

Fig. 3. Functional zoning of Vodlozersky National Park. Functional zoning of the Vodlozersky biosphere reserve.

The national Park Ugra [8] received the status of biosphere reserve at the end of 2002. The boundaries of the reserve included the entire territory of the Park, as well as its security zone. The zoning scheme of the reserve is organically combined with the zoning scheme of 
the national Park: the core zone consists of 5 sections of the protected zone, as well as the subzone of ecological stabilization of the specially protected zone; the buffer zone includes the remaining part of the specially protected zone, as well as the protection zone of historical and cultural objects; the protected landscape area along with the other remaining ones, and the external protection zone of the Park are allocated as a transition zone, which made up $78.8 \%$ of the total area of the reserve. The Park includes 62 settlements with a total number of indigenous inhabitants of 2500 people, and the biosphere reserve of 138 settlements and more than 13,000 inhabitants. As the Russian experience shows, the tasks and goals of biosphere reserves are comparable to the tasks of national parks.

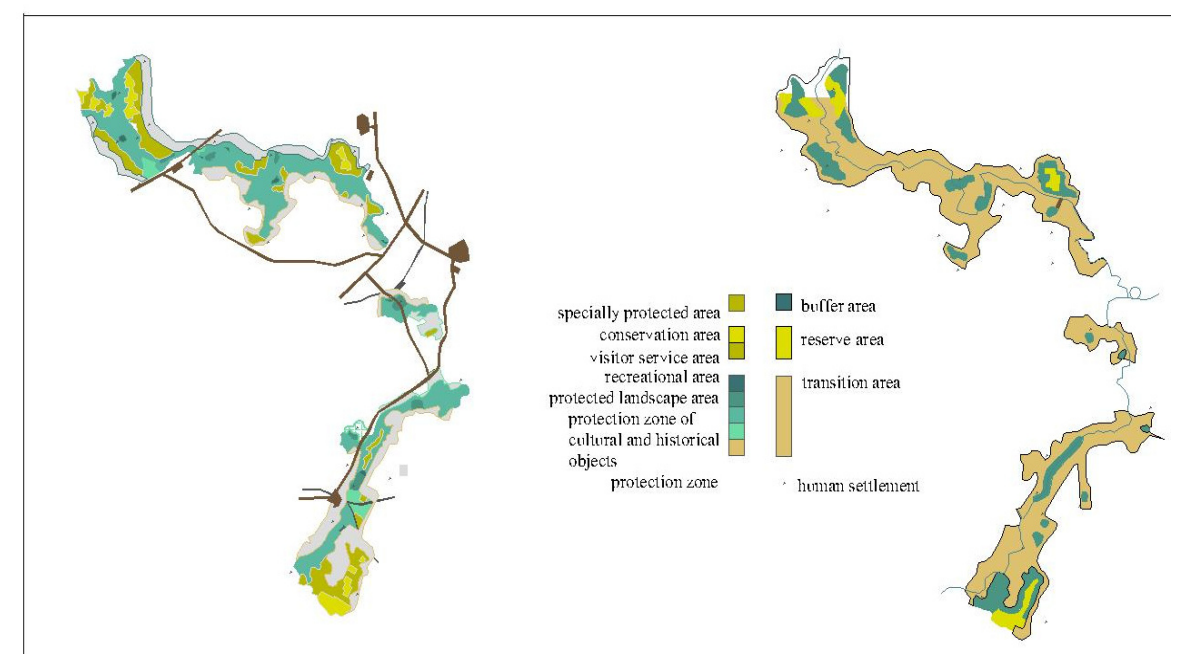

Fig. 4. Functional zoning of the Ugra National Park. Functional zoning of the Ugra Biosphere reserve.

Conservation. The special value of the territory is the diversity of cultural landscapesintegral territorial complexes that have arisen because of the interaction of man and nature. Typologically, these include peasant, rural, and Park complexes, manors, monastic landscapes, etc. In the national Park, developed a strategy for their conservation, maintenance and restoration.

The priority themes of scientific research of cultural and historical heritage are programs for the study and preservation of traditional folk culture (types of buildings and settlements). Efforts are being made to restore the heritage. The works of this plan include historical reconstruction of noble estates, restoration of Park ensembles, and landscape arrangement of ancient settlements.

Promotion of social and economic development. The strategic direction of development of the Park and the biosphere reserve is the tourism sector, which offers a large range of services with the direct participation of local residents:

- Development of a network of rural guest houses for families and individual services for small groups;

- Arrangement and maintenance of tour stops on the river Ugra and Zhizdra for touristswater-transport workers;

- The organization of service of autotourists in traditional places of rest;

- Arrangement of places of mass rest of the day off and rendering of the accompanying services to visitors;

- Development of a network of ecological trails;

- Excursion service for visitors; 
- Organization and holding of mass traditional folk festivals.

The national Park held a tender for the provision of sites and facilities of the Park for the development of tourism infrastructure, a network of private guesthouses is being formed.

In the transition zone of the biosphere reserve, the national Park interacts with local entrepreneurs. The project of a tent camping Sukovka on the Bank of the Ugra River, which is equipped according to the sketches of the national Park and accepted for service by local entrepreneurs, was implemented. A grant from the world wildlife Fund with the participation of local residents and schoolchildren has been used to create an ecological trail in the area of Nikola-Lenivets. Together with the local folk ensemble revived the tradition of folk festivals Trinity, Maslenitsa, Seeing the Sun.

In the national Park, there are several examples of successful cooperation with farmers, the experience of which is distributed among the local population: horticulture of V.N. Morozov in village Lublinka, beekeeping farm of the family of Shipovs in Dzerzhinsky district, hay farm of I. I. Pugachev in the floodplain of the river Zhizdra. The maintenance and improvement of the peasant-rural landscape involves the restoration of traditional forms of agriculture and cattle breeding, beekeeping and horticulture, construction and other crafts necessary for the arrangement of living space and life [15]. The priority task of the biosphere reserve is the development of partnerships with the local population, modeling of joint management of the territory

\subsection{Legally approved functional zoning of national parks}

According to the Federal law of the Russian Federation "On protected areas" [9], approved in 1995, of all protected areas only national and natural parks are subject to zoning. The number of functional areas depends on the natural features of the territory and the nature of its use. The boundaries of functional zones needs to pass through well-defined linear landmarks: the watersheds of the rivers, roads. According to the Federal law on protected areas, up to seven zones can be allocated in the national territory:

1. Conservation area. The main function-preservation of natural complexes and objects in their natural state, any activity including recreational is forbidden;

2.Specially protected zone. Providing conditions for the preservation of individual natural complexes and objects; it is possible to visit subjects of strict regulation on specially equipped routes without accommodation. It serves as a buffer for areas of the protected zone. A specially protected zone may have subzones: for example, subzones of environmental stabilization in the Ugra National Park [33].

3. The area of cultural tourism. The organization of ecological education and acquaintance with the sights, any violation of aesthetic perception of landscapes, violation of habitats and ways of migration of animals are forbidden. Within the limits of this zone it is allowed:

- equipment of routes of different types, including their marking and creation of small architectural forms;

- the device of Parking for rest and overnight;

- equipment of natural or artificial observation platforms and exposition areas for animal observation;

- equipment of places for swimming and recreation on the water, construction of berths;

-construction and equipment of educational nature trails;

- establishment of information centres and points.

4. Recreational area. Creating conditions for recreation in a natural environment. In the recreational area develops road and path network, construction of Parking lots, greenhouse, 
playgrounds and places of recreation. Accommodation and long stops are allowed in specially designated and equipped places;

5. Protection zone of historical and cultural sites. Providing conditions for the preservation of historical and cultural sites, recreational activities are coordinated with the state bodies of protection. Placement and architectural design of objects should not violate the historical appearance of the landscape;

6. Visitor service area. Accommodation of places of accommodation, tent camps and other objects of tourist service, cultural, consumer and information service of visitors); created in planning nodes (most often timed to settlements or recreation facilities). There can be built stationary objects of tourist service year-round and seasonal action (hotels, motels, campsites and shelters), environmental information centers (visit centers), nature museums. The objects of cultural and household purposes and administrative and economic infrastructure of the national Park are also being built. Access roads and Parking lots are equipped, berths are built, beaches are arranged;

7.Zone of economic purpose. Implementation of economic activities necessary to ensure the functioning of the national Park. National parks are created in areas inhabited by indigenous people, is allocated the territory of traditional nature. The regime of this zone is aimed at maintaining the sustainable use of natural resources, including the development of Handicrafts and folk crafts, timely restoration of confiscated natural resources, the use of environmentally friendly methods in agriculture and the preservation of the appearance of the existing cultural landscapes. At the same time, the Russian population also belongs to the indigenous population. The construction of new economic facilities and facilities is prohibited here. Around the national Park is created a protective zone that protects it from adverse effects. In the protected zone, projects for the development of settlements and the provision of land plots are being coordinated.

The territory of the Ergaki natural Park in accordance with the legislation of the Russian Federation and the Krasnoyarsk territory, different regimes of protection and use are established depending on the environmental and recreational value of natural sites:

1. The special protection zone occupies $15.8 \%$ of the Park territory and is located in the East of Ermakovsky district. This area is a protected core of the Park, which is prohibited to find, travel and pass out of public roads

2. Recreational and tourist area, which occupies $49.9 \%$ of the Park. It is open to visitors and organized tourism;

3. The zone of traditional nature management $-31 \%$, consists of two cluster areas "Ambuk" and "Us". The residents of Ermakovsky district are allowed to carry out traditional economic activities (harvesting of food forest resources, medicinal plants, hunting under nominal one-time licenses).

4. Economic zone, which occupies $2.6 \%$ and consists of 4 cluster plots. The economic zone is designed for the construction of tourism, recreation, sports complexes and facilities necessary for the operation of the natural Park.

\section{Results}

Thus, the territory of the natural Park is divided into 4 functional zones. Of these, recreation, tourism and economic combine 2 functional zones, allocated in the Federal law on protected areas. Recreation and tourism combines zones of educational tourism and recreational zone, and economic: the zone of service of visitors and economic. 
Table 1. Comparative characteristics of functional zoning of biosphere reserves, national parks and ecotourism territories

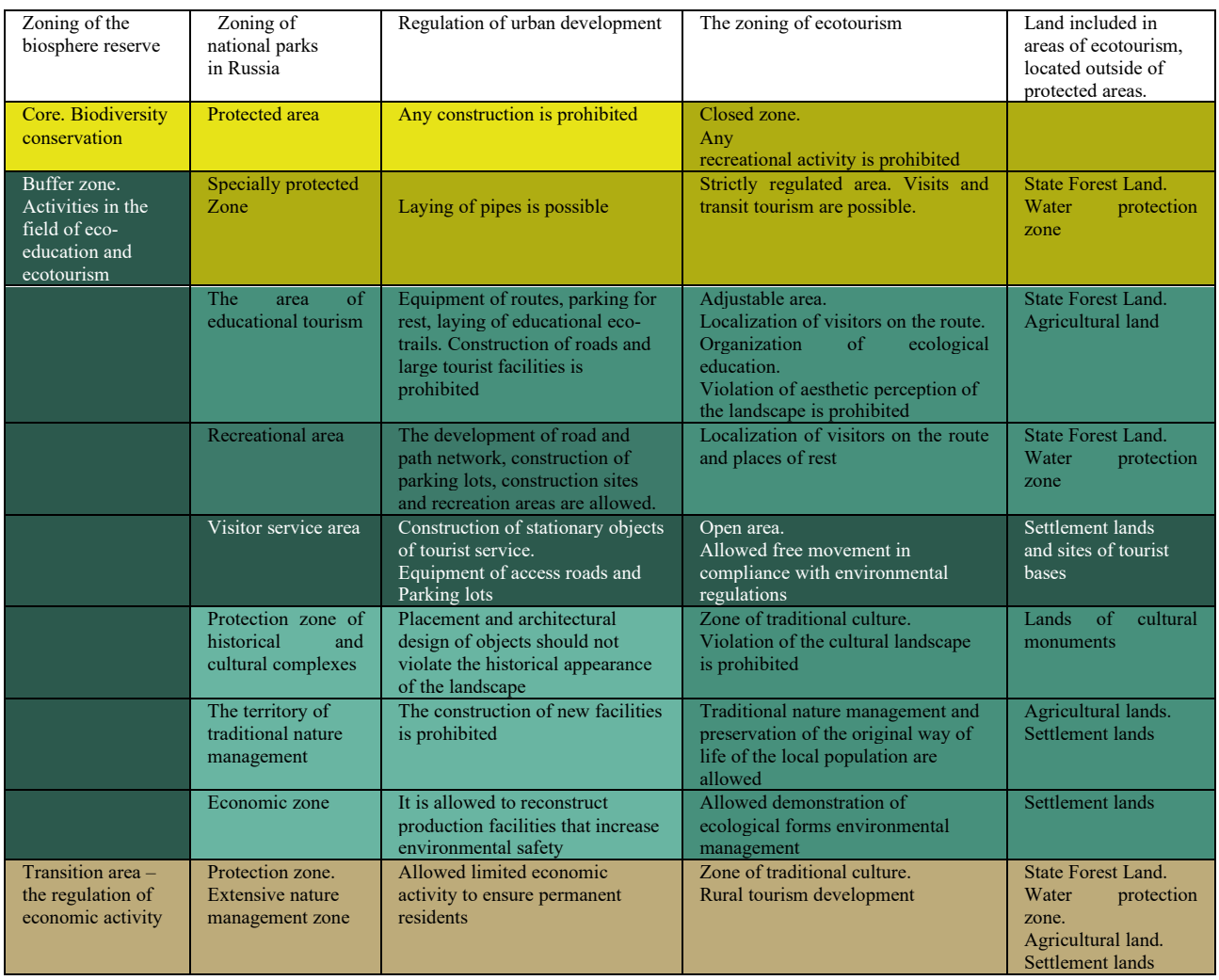

Ecological tourism is mainly carried out in the territories of protected areas, but can also go beyond the protected areas. The scheme of functional zoning should allow to organize the recreational area in such a way that economic, recreational and environmental functions are combined on it in the most optimal way. For this purpose, zones of special protection (state Forest lands and water protection zones: only transit tourism is possible), regulated recreational use (state Forest lands and agricultural use), visitor service (settlement lands and sites of tourist bases: reconstruction and construction of tourist service facilities are allowed), municipal and economic (settlement lands) and traditional land use (agricultural land).

According to Strasdas [20] and Ceballos-Lascurain [10-11] (the main ways of tourism management in protected areas), it is necessary to allocate strict protection zones, where any recreational activities are prohibited, restricted areas, where it is possible to walk along the trails accompanied by a guide, areas with a moderate mode of use, there may be a limited number of infrastructure facilities (ecological trails, observation platforms), areas of intensive use, where there is an improved infrastructure (recreation and overnight, roads, trails, observation towers), infrastructure areas, where are the main objects of tourism infrastructure, and sports fishing zone.

Khromov $\mathrm{Yu}$. B. proposed to zone recreational area. For this purpose, it is planned to create recreational areas with different allowable density of visitors per time unit. On the territory of the natural Park he distinguishes the following areas: the most intensive use; 
intensive use; extensive use; long-term restoration of the landscape with the possible use of the territory for tourism as the landscape is restored; the territory for short-term walking.

The functional zoning of the ecotourism territory is influenced by the tourist structure of the territory, the structure of which is determined by the presence of the main sources of recreational demand and landscape-route corridors between them. As a result of the analysis, the following zones can be identified according to the degree of regulation of urban development, openness to tourists, the mode of use:

1.Areas closed to tourists are key natural areas or the core of the ecological framework, areas of strict protection, closed due to the vulnerability of the environment and the incompatibility of tourism with scientific research. This includes protected and specially protected areas, specially protected areas with seasonal and temporary protection of endangered species of animals and plants, the territory of temporary ecological rest or ecological restoration (if the monitoring results showed the deterioration of natural complexes as a result of tourist activities) in the protected areas. Outside the protected areas it can be water protection zones and lands of the state Forest [11]. The main goal of this zone is to preserve biodiversity. The size of this zone should enable the ecosystem to function. Any capital construction and recreational activities are prohibited here.

2. The zone of strict regulation is a specially protected zone, visit of which is possible only under the condition of strict regulation accompanied by a guide, transit tourism is possible. The infrastructure of this zone is minimal and can consist only of hiking trails.

3. Regulated zones are recreation and tourist zones of national and natural parks (zones of cognitive tourism, recreational), buffer zones of biosphere reserves, territories of landscape and route corridors, lands of the state forest Fund [12] and agricultural purposes. Managed zones are areas of regulated recreation and educational tourism, where conditions are provided for the demonstration of natural phenomena for the purpose of environmental education and, at the same time, measures are taken to preserve the natural landscape and the free movement of migratory animals. Here the presence of tourists is allowed under control. Visitors are localized on the route or place of rest. Tourist infrastructure is limited. In this zone can be equipped with tourist Parking, paved routes, equipped with pointers and garbage collection points, used wooden decking, excluding trampling, built observation platforms, allowing you to photograph animals, while limiting the load on them. The construction of roads and major tourist facilities should be prohibited in the managed areas. The most acceptable is the use of mobile tourist facilities and tourist shelters located within walking distance from the tourist attraction.

4. Open areas where tourists can move freely, observing environmental regulations. These are zones of accommodation and service of tourists in protected areas, lands of settlements and sites of tourist bases, providing conditions for recreation and accommodation in tourist institutions, dispersal of tourist flows. Here the main stationary tourist institutions (tourist bases, hotel complexes, visit centers) are concentrated, access roads and Parking lots are equipped. The location of the open zone depends on the existing transport network and the area of concentration of the main natural attractions.

5.Zones of traditional culture consist of zones of traditional nature management, lands of settlements and agricultural lands, lands of the state Forest [13] and water protection zones, where the original way of life of the local population is preserved and the traditional nature management for the area is allowed. Hunting, fishing, harvesting of berries and mushrooms can be allowed within its limits. The rules of conduct of tourists depend on traditional nature management to preserve the way of life of the indigenous population. In this zone it is possible to demonstrate ecological forms of nature management, development of rural tourism, development projects of which are coordinated with the administration of protected areas. Expansion and construction of new economic facilities is prohibited. 


\section{Conclusions}

Open area - here are planning centers with a full set of planning elements.

Regulated zone - planning nodes with a limited set of planning elements, mainly a road and tropical network with

the presence of short-term seasonal and mobile tent tourist institutions, such as tent camps, tourist shelters and huts.

Strictly regulated area can develop the only the footpath network.

In the settlements of the area of traditional culture there may be the location of planning nodes with a full set of

planning elements. Outside the settlements-depending on the cultural component, the set of planning elements can correspond to areas from strict protection to the open zone.

\section{References}

1. V. V. Vladimirov, N. I. Naimark, G. V. Subbotin Handbook of the (Moscow: Stroizdat, 1986)

2. Kotlyarov, E. A. Geography of recreation and tourism: Formation and development of territorial recreational complexes ( Moscow, Thought, 1978)

3. Vodlozersky national Park: natural diversity and cultural heritage. Petrozavodsk: KRC of RAS, 314 (2001)

4. Khromov, Yu. b. Organization of recreation, tourism and protection of the natural environment in the North: production and practical edition (Stroiizdat, 1981)

5. Ceballos-Lascuráin, H. McNeely, J. A., Thorsell, J. W. Guidelines: development of national parks and protected areas for tourism. (Monographic Series, 13, 1992)

6. Ceballos-Lascuráin, H. Tourism, ecotourism, and protected areas: the state of naturebased tourism around the world and guidelines for its development. Conference: World Congress on National Parks and Protected Areas, 4th, Caracas, VE, 10-21 301, (1996)

7. Amirkhanova, E. A. Features of the functional biosphere reserve Schorfheide-Horin (Germany) / E. A. Amirkhanova, Geography and natural resources, 145-151, (2007)

8. Litvinova, E. M. Ecosystem services of the Valdai national Park and their promotion for education for sustainable development, seminar "Sustainable development of biosphere reserves in the Volga river basin", 4, 25-28, (2010)

9. I. M. Yakovenko, A. B. Voronina, Specially protected natural territories as an object of recreational activity, Uchen. zap. Crimea. federal soldier. UN-TA im. V. I. Vernadsky. Ser. Geography. Geology, 12, 41-60, (2015)

10. Blamey, R. K. Journal of Sustainable Tourism, 15, 109-130, (1997)

11. Ross, S., Wall, G., Ecotourism: towards congruence between theory and, Tourism Management, 7, 123-132 (1999). 